\title{
Effectiveness of Secondary School Boards in Managing Students' Discipline among Public Secondary Schools in Ulanga District, Morogoro Tanzania
}

\author{
Anunsiata T. Liguluka* and Daniel Oduor Onyango, PhD \\ Department of Education Foundations, St. Augustine University of Tanzania \\ *Email: anunsiataliguruka@gmail.com
}

\begin{abstract}
The purpose of this study was to investigate the effectiveness of secondary school boards in managing students' discipline among public secondary schools in Ulanga District, Tanzania. The study employed mixed research approach and convergent parallel research design. The researcher used stratified sampling and simple random sampling methods to select 75 out of 298 teachers and 76 out of 324 student leaders. Purposive sampling was used to select one (1) District Education Officer, one (1) Standard Quality Assurer, one (1) Ward Education Officer, four (4) Heads of Schools and four (4) Chairpersons of School Boards. Data was collected using questionnaires, interview guides and documents. Data was analyzed through descriptive statistics and thematic approach. The study revealed that although school boards discussed discipline issues in public secondary schools, they did not take any appropriate disciplinary action such as discontinuing students with disciplinary issues, warning or suspend the students. The study recommended that apart from discussing about disciplinary issues, school boards should take appropriate disciplinary actions such as suspending discontinuing and giving warnings to the students with disciplinary issues. It is recommended that the school boards should ensure constant communication with disciplinary committees to maintain students' discipline in schools. The study further recommended that the government should enhance budgetary allocations to the schools for better effectiveness of discipline management. The Heads of schools and board members should be trained on effective leadership and the parents should be educated on the importance of cooperation in managing students' discipline in public secondary schools.
\end{abstract}

Key Words: Effectiveness, School Boards, discipline, secondary schools, Ulanga, Tanzania

\section{Introduction}

Student discipline in secondary schools is a pillar of effective teaching and learning which results in improved academic performance. However, a number of studies point out that schools are globally in trouble (Senge, et al., 2000). Mohapi (2013), for instance, states that indiscipline among secondary school learners is a major school issue that greatly involves parents, researchers, educators, politicians and public speakers, which school boards should react to. In the USA, during the 2015-2016 school year, the local board of education took actions against disciplinary cases whereby 37 percent of the disciplinary actions were taken by School Board in response to students' involvement in the use and possession of a weapon and firearms or explosive devices.

A key condition for the effectiveness of the learner code of conduct lies in its enforcement. In this regard, Nitsch, Baetz and Hughes (2005) assert that one of the determinants of the effectiveness of a code of conduct is the degree to which violations of the code can be appropriately addressed. In the same vein, by virtue of its governance mandate, the school board delegates the day-to-day enforcement of the code of conduct to the school management team and teachers in most countries. The procedure of doing so are clearly spelt in policy documents provided by various ministries of education. Mestry, Raji and Khumalo (2012) conducted a study on 
effectiveness of and factors impeding the enforcement of learner codes of conduct in rural secondary schools in South Africa. Using a generic qualitative research design involving group interviews, the study found that many rural school governors still lack the relevant knowledge and skills to design and enforce the learner code of conduct effectively.

While in Tanzania most secondary school board members do not understand their responsibilities, the trend has affected their effectiveness in managing discipline of the students (Mtewele, 2012). Further, statistics from National Bureau of Statistics of Tanzania revealed that 93.2 percent of school dropouts in government schools were attributed to truancy while 5.6 percent was attributed to pregnancy and 1.2 percent to death (URT, 2016).

According to a report of Ulanga District, 250 cases of truancy and 13 cases of pregnancies were reported between January and March, 2020 (URT, 2020). In response to that, the government of Tanzania has been implementing educational policies and programs spelt out in the Education Act 1978, the Education Training Policy of 1995 and Government School Order of 2002 with the aim of enhancing the role of school boards in maintaining students' discipline in public secondary schools among other roles (URT, 2010). Despite the foregoing efforts to ensure effectiveness of school boards in managing students discipline in public secondary schools, cases of indiscipline have continued to rise from time to time especially in developing countries such as Kenya and Tanzania (Kindiki, 2009; Simelane, 2017; URT, 2016; URT, 2020).On the basis of this background, this study sought to establish the effectiveness of secondary school boards in managing students' discipline in public secondary schools in Ulanga District, Tanzania. The study sought to answer the following research questions:

1. To what extent are School Boards involved in handling students' discipline in public secondary schools in Ulanga District?

2. What challenges do school boards face in managing students discipline in public secondary schools in Ulanga district?

\section{The Extent to which Secondary School Boards} Handle Students' Discipline

Discipline in secondary schools is a pre-requisite to successful teaching and learning, hence academic excellence.
Outside and within Africa, various studies have shown that discipline in secondary schools is the responsibility of not only heads of schools, teachers and parents but particularly school boards that are considered the highest organs in the schools. For instance, in USA, Beckham and Wills (2020) looked at the legal basis for the disciplinary function of school boards, their responsibilities, decision making and leadership. The study found that school boards were empowered to use various initiatives in managing students' discipline; the study further revealed that activities such as frequent guidance and counselling were crucial for the effectiveness of school boards in managing discipline in schools. Consequently, they emphasized the role of adequate training to enhance the capacity of school boards in undertaking their roles such as ensuring accountability and managing discipline in schools.

Tatlah and Iqbal (2012) conducted a study entitled the role of the board of governors and parentteacher associations in District Public Secondary Schools in the context of conflicts and challenges in Pakistan. The study revealed that school heads and disciplinary masters were seen as the only persons that have the responsibility to ensure students' discipline. In the same vein, using a quantitative research design, Kija (2015) conducted a study on the contribution of school boards in managing community secondary schools in Rombo, Tanzania using a mixed research design. The study found out that the school boards enhanced good oversight in education and training institutions by ensuring accountability in the use of school resources.

\section{School Boards' Challenges in Managing Students' Discipline}

Botha (2012) conducted a study on the roles of the school principals in the school governing entities in South Africa. The study was based on qualitative research approach. In his study, he mentions one of the challenges faced by the school board to be that, they experienced difficulties in working with school management teams because they did not always implement the decisions taken at the school board meeting. The government should therefore empower school boards by enacting laws and rules that empower members of the school boards, including disciplining school heads who do not implement decisions made by the boards for the benefits of the school community and the nation at large. Moreover, a study by Onderi and Makori (2013) in Kenya about the challenges in achieving effective school leadership and management 
focused on the role of Boards of Governors (BOGs) and Parent-Teacher Associations (PTA) in Kisii Country through the survey design using the questionnaires as a means to collect data. The study findings identified some challenges such as lack of adequate funds and parental support. The study recommended that for the schools to achieve their planned objectives, the government and education stakeholders should ensure they provide adequate resources including funds to enhance schools achieve their planned goals.

Through the qualitative and some elements of the quantitative approaches, Sulley (2016) in Tanzania conducted a study on the challenges the school boards faced in managing community secondary schools. The study findings showed that the performance of the school boards was greatly affected by the lack of sufficient funds, lack of training and poor cooperation between school boards and other stakeholders. Without sufficient funds it is not possible for schools to host regular meetings between students and discipline committees. Therefore, the government needs to ensure that adequate funds are allocated and distributed on time to schools to facilitate among other school operations, training of board members and facilitating their regular activities geared towards managing students' discipline in schools.

From the literature review, different studies have been done by different scholars especially in USA, South Africa and Kenya on the roles and challenges of school boards in managing students' discipline in schools (Beckam and Wills, 2020; Botha 2012 and Onderi \& Makori 2013). However, most of these studies employed either qualitative or quantitative approach. This study sought to employ a mixed research design. While some studies conducted in Tanzania were in Kilimanjaro and Arusha which are distinct regions (Kija, 2015; Sulley, 2016), the he researchers in this study sought to fill the geographical gap by focusing in Ulanga District.

\section{Research Methodology}

This section presents the research design, population and sampling techniques, instruments used, validity and reliability as well as the statistical treatment of data.

\section{Research Design}

This study adopted a convergent parallel research design. Convergent parallel design involves collecting simultaneously qualitative and quantitative data. The data were analyzed separately and then merged during the interpretation for a better understanding by the reader (Creswell, 2014). This design enabled the researchers to collect more data on the effectiveness of school boards in managing students' discipline. The data collection methods complemented each other to overcome the weaknesses of each individual method and hence the problem was studied extensively.

\section{Population and Sampling Techniques}

The target population of this study was seven hundred thirty one (731) subjects from four public secondary schools consisting of one (1) District Education Officer, ninety (90) members of the Boards of management, eighteen (18) Heads of Departments, two hundred and ninety eight (298) secondary school teachers and three hundred and twenty four (324) student leaders.

The researcher used stratified sampling and simple random sampling methods to select 75 out of 298 teachers and 76 out of 324 student leaders. This sampling technique helped to eliminate biases by having representatives randomly per group (Oso and Onen, 2016). Secondly, purposive sampling was used to select one (1) District Education Officer, one (1) Standard Quality Assurer, one (1) Ward Education Officer, four (4) Heads of Schools and four (4) Chairpersons of School Boards. The selective respondents were chosen because they are experienced and due to their positions, they possessed useful information about the topic under investigation (Creswell, 2014).

\section{Instruments and Data Collection Procedures}

The study employed both open and closed ended questionnaires, interview guides and documents as sources of data. Consequently, semi-structured interview guides were used to interrogate the heads of public secondary schools, the District Education Officer, the Standard Quality Assurer, WEO and chairpersons of school boards of respective schools so they could provide specific and detailed information on the effectiveness of school boards in managing students discipline in public secondary schools in Ulanga District (Pickard, 2013). Finally, document analysis was used to determine the frequency of school board meetings from the available minutes and to find out the disciplinary measures taken on indisciplined students (Boudah, 2011). 


\section{Validity and Reliability}

The researchers conducted regular consultations with research experts who supported the process of validating the tools. This enabled the researchers to polish, reshape and re-write the questionnaire (Mohajan, 2017). In addition, the researcher tested the reliability of the research instruments through test re-test method which showed that the instruments were reliable since after the pilot study, the sets of data were correlated to check on the consistency of the responses. The reliability of documents was checked by the existence of signatures of the responsible persons and the official rubber stamps.

\section{Statistical Treatment of Data}

Qualitative data obtained from semi-structured interview and open-ended questionnaires and the documents were analyzed and presented based on thematic approaches. The data was then presented through reporting and explaining what the respondents were saying. On the other hand, quantitative data obtained from closed- ended questionnaires were coded using SPSS version 21 and analyzed using descriptive statistics.

\section{Findings and Discussion}

The study sought to investigate the effectiveness and challenges of secondary school boards in managing students' discipline in public secondary schools in Ulanga District. Specifically, the researchers sought to find out the extent to which school boards handled students discipline and the challenges faced by school boards in managing students' discipline among public secondary schools. This section therefore presents the results and discussions.

Research Question 1: To what extent are School Boards involved in handling students' discipline in public secondary schools in Ulanga district?

The first research question aimed to determine the extent to which school boards engaged in handling students' discipline in public secondary schools in Ulanga District as presented in Table 1.

Table 1: Extent to which School Boards Handle Students' Discipline

\begin{tabular}{llccc}
\hline SN & \multicolumn{1}{c}{ Item in the questionnaire } & Mean & Std. Dev & Interpretation \\
\hline 1 & School boards discusses and act on discipline issues & 2.5166 & .66186 & Agree \\
2 & School boards suspend indisciplined students & 2.4636 & .66106 & Disagree \\
3 & School board tends to favor students in getting punishment & 2.4570 & .78090 & Disagree \\
4 & School boards discontinue indisciplined students & 2.4437 & .72696 & Disagree \\
5 & School boards give warning to indisciplined students & 2.4172 & .68661 & Disagree \\
6 & School board communicates with the discipline committee & 2.4106 & .69543 & Disagree \\
\hline
\end{tabular}

Key: 1.00-1.49= Strongly Disagree, 1.50-2.49= Disagree, 2.50-3.49= Agree, 3.50-4.00= Strongly Agree

Table 1 indicates the perception of respondents on the extent to which school boards handle students' discipline in schools under investigation. The mean scores for items in the questionnaire arranged in a descending order that means from the most agreed to the most disagreed. As seen in the table, the mean score for the first item ranged between 2.50 and 3.49 which means respondents agreed that school board discussed and acted on discipline issues. The mean score for the rest of the items in the table ranged between 1.50 and 2.49 meaning respondents disagreed with all the items. Particularly, they disagreed that the school boards suspend indiscipline students. This suggests that the school boards did not exercise their powers effectively in managing students' disciplines.

Respondents further disagreed that school boards tend to favor students in getting punishments. This suggests that the school board supported recommendations made by the lower committees on how to administer punishments to indiscipline students.

Furthermore, respondents disagreed that the school boards discontinued indiscipline students, gave warnings to indiscipline students and communicated with the discipline committees. This suggests. A communication gap between the disciplinary committees and the school boards and the ineffective follow up by the school board leaders. This is against what Simelane (2017) recommended that secondary schools should ensure a supportive environment for disciplinary measures to be taken as required. The author further adds that warning the misbehaved students is very important because it will help to shape the students' behavior and at the end will help to maintain students' discipline. Therefore, school boards should not only discuss the disciplinary issues, but also they have to give warnings, suspension and even discontinue the 
misbehaved students through applying the school rules and regulations.

The interviews conducted showed that in some schools, the school boards took no required disciplinary measures and actions. These were attributed to disagreement among board members themselves and parents on suspension of indisciplined students.

Similarly, with regard to the first research question, the researcher sought to establish whether the school boards held meetings with students to discuss discipline issues as reflected in Table 2.

Table 2: School Boards Meeting with the Students

\begin{tabular}{lcc}
\hline \multicolumn{1}{c}{ Item } & Frequency & Percent \\
\hline Yes & 35 & 46.1 \\
No & 41 & 53.9 \\
Total & 76 & 100.0 \\
\hline
\end{tabular}

Results from table 2 show that 46.1 percent of the respondents reported that school board met with students to discuss disciplinary issues while 53.9 percent indicated that school boards did not meet with students to discuss discipline issues in public secondary schools. Similarly, analysis of minute's files for school board meetings revealed that there were irregular meetings in a year. This implies that most school boards rarely met with students to discuss the discipline issues despite the fact that meetings between school boards and students give an opportunity for students to share their challenges and to discuss issues concerning their discipline for informed decisions. Furthermore, regular meetings could help the school boards to understand different challenges which students faced in order to give appropriate recommendations. In addition, frequent meetings between students and the school boards will ensure students are involved in decision making concerning their discipline issues. On the contrary, Kasimu (2015) shows that students in most secondary schools were not involved in making decisions on issues affecting their discipline and suggested that motivational talk programs and peer counseling facilities should be adequately provided in schools to enhance students' discipline.

Research Question 2: What challenges do school boards face in managing students discipline in public secondary schools in Ulanga District?

The findings to this research question are presented in Table 3 where 30.5 percent of the respondents reported the challenge of inadequate funds to facilitate regular meetings of school boards of management while 29.8 percent reported disunity between parents and school board members. Furthermore, 20.5 percent pointed to weak school leadership and 19.2 percent indicated disagreement among board members on the type of punishment to be met on students involved in indiscipline cases as some of the challenges facing school boards in managing students' discipline among public secondary schools in Ulanga District.

Table 3: Challenges faced by secondary school boards in managing students' discipline

\begin{tabular}{llcc}
\hline SN & \multicolumn{1}{c}{ Category } & Frequency & Percentage (\%) \\
\hline 1. & Disunity between parents and school board members & 45 & 29.8 \\
2. & Shortage of fund which hinders their frequency meetings & 46 & 30.5 \\
3. & Disagreement among board members on type of punishment & 29 & 19.2 \\
4. & Weak school leadership & 29 & 20.5 \\
& Total & $\mathbf{1 5 1}$ & $\mathbf{1 0 0 . 0}$ \\
\hline
\end{tabular}

In the same vein, in an interview with the head of one of the schools under investigation revealed that:

there is lack of funds for running regular school board meetings and this is because the government has failed to provide enough funds for running different activities concerning school boards and as the result, this has affected the management of students' discipline (Interview with a Head of School).
Similarly, through document analysis, the researchers established that the school boards meet rarely per year. When one of the researchers asked the question to one of the school administrators it was revealed that the school board has expired and names for new board members had been sent to the Regional Educational Officer but they didn't receive the feedback and hence they remained without the school board. 


\section{Conclusions and Recommendations}

This part gives the conclusion as well as the recommendations based on the findings of the study.

\section{Conclusions of the Study}

Based on the first research question on the extent to which school boards are involved in managing students' discipline, the study concludes that the major role played by the school board members is discussion about disciplinary issues without necessarily taking appropriate disciplinary actions such as suspending, discontinuing and giving warnings to the students with disciplinary issues. Furthermore, the school boards did not communicate with disciplinary committees on regular basis.

With regard to challenges faced by school boards in managing students' discipline, the study concluded that, secondary school boards were not effective due to challenges such as disunity between parents and school board members, shortage of funds, opposition among board members and weak school leadership.

\section{Recommendations of the Study}

Based on the conclusions of the study, the researchers recommend that apart from discussing about disciplinary issues, school boards should take appropriate disciplinary or corrective measures such as suspending, discontinuing and giving warnings to the students with disciplinary issues. Furthermore, the school boards should ensure constant communication with disciplinary committees in order to maintain students' discipline in schools.

With regard to challenges faced by school boards in managing students' discipline, the study recommends that the government should enhance budgetary allocation to schools under investigation for effective implementation of disciplinary measures. Furthermore, heads of schools and board members should be trained on effective leadership and the parents be educated on the importance of cooperation in managing students' discipline in the schools.

\section{Reference}

Beckham, J. \& Wills, K. B. (2020). Responsibilities, duties decision making and legal basis for local school board powers. Web solutions LLC and its Licensors. U.SA.
Botha, R. J. (2012). The roles of the school principals in the South African school governing body: A case study of various member perceptions. South African Journal for Social Science, 30(3), 263-271.

Boudah, D. J. (2011). Conducting educational research: Guidance to completing a major project. Los Angeles: Sage Publication.

Creswell, W. J. (2014). Research design: Qualitative, quantitative, and mixed methods. New York: SAGE Publlication

Kasimu, M. J. (2015). Influence of board of management practices on students' discipline in public secondary school in Kibwezi sub county, Kenya. (Published Master's project), University of Nairobi, Kenya.

Kija, M. (2015). Contribution of school boards in managing community secondary schools in Rombo District. (Published Master's dissertation). The Open University of Tanzania.

Kindiki, J. N. (2009). Effectiveness of boards of governors in curriculum implementation in secondary schools in Kenya. Journal of Educational Research and Reviews, 4(5), 260-266.

Mestry, Raj and Khumalo (2012). Governing bodies and learner discipline: managing rural schools in South Africa through a code of conduct. South African Journal of Education, 32(1), 97-110. Retrieved December 11, 2020, from http://www.scielo.org.za/scielo.php?script= sci_arttext\&pid=S025601002012000100008 \&lng=en\&tlng=en.

Mohajan, K. H. (2017). Two criteria for good measurements in research: Validity and reliability. Annals of Spiru Haret University 17(3), 58-82.

Mohapi, S. J. (2013). The influence of Ndebele cultural practices in school discipline in two secondary schools in Mpumalanga province, South Africa. Mediterranean Journal of Social Sciences 4(11), 376-383.

Mtewele, G. C. (2012). The influence of traditional customs and practices on girls' secondary education in Morogoro region in Tanzania. 
(Unpublished master's dissertation). University of Oslo, Norway.

Nitsch, D, Baetz, M and Hughes JC (2005). Why codes of conduct violations go unreported: A conceptual framework to guide intervention and future research. Journal of Business Ethics 57,327-341.

Onderi, H., \& Makori, A. (2013). Challenges in achieving effective school leadership 262 and management in Kenya: A case of the role of BOGS and PTAS in the Kisii country. International Journal of Advance Research in Management and Social Sciences, 2 (1), 263283. Retrieved from http://www.graph.co.uk

Oso, W. Y. and Onen, D. (2016). Writing research proposal and report. A handbook for beginning researchers. Nairobi. Ramco Printing Works.

Pickard, A. J. (2013). Research method in information: A guide for students in the helping research professions $\left(2^{\text {nd }} E d\right)$. London: Facet publishing.

Senge, P, Cambron-McCabe N, Lucas T, Smith B \& Dutton J. (2000). The Fifth Discipline. Schools that learn. New York: Random House.
Simelane, G. S. (2017). Stakeholder perceptions of effect of indiscipline on academic performance of learners in selected Bushbuckridge rural schools. (Published Master's dissertation). University of South Africa. South Africa.

Sulley, J. D. (2016). Challengs faced by school boards in managing community secondary schools: The case of Kiteto district-Manyara Region. (Published master's dissertation). University of Dodoma, Tanzania.

Tatlah, I. A. \& Iqbal. Z. (2012). Role of board of governors and parent teacher associations in district public schools: in the context of conflicts and challenges. (Published master's dissertation). University of Lahore, Pakistan.

URT (2010). Education sector development programme. Dar es Salaam.

URT (2016). President's office reginal administration and local government: Pre-primary, primary and secondary education statistics in Morogoro Region. Tanzania

URT (2020). President's office reginal administration and local government. Secondary education statistics in Ulanga District, Morogoro. Tanzania 